couenneuse, contained in the "Gazette Hebdomadaire," also draws attention to diphtheritic paralysis, of which he adduces four cases. He regards it as a complication occurring mainly in the adult, that its duration is from two to three months, that the effect of treatment is very doubtful, and that it depends upon a serous alteration of the blood, the restoration of which is essential to recovery. Dr. Bouillon-Lagrange asks why this important complication has scarcely been noticed in previous epidemics, and is inclined to attribute it to the modifications in the epidemies of 1857 and 1858 by the continued dryness of the atmosphere which accompanied their development and progress.-Brit. and Foreign Medico-Chirg. Review, from Arch. Gén. de Méd.

\title{
A CASE OF NEW FORMATION OF GREY CEREBRAL MATTER.
}

\section{BY DR. C. TUENGEL, OF IIAMBURGI.}

A FEMale, aged thirty-one, was brought into the Hamburgh Hospital on the 26th November, 1858, in a state of sopor; she only gave short replies when repeatedly questioned, and without having understood the questions; she occasionally uttered brief exclamations. When attempts were made to open the eyes, she closed them convulsively; attempts at moving any of the limbs were resisted, but this was easily overcome, except the spasmodic contraction of the right hand. There was a dislocation of the right arm inwards. Respiration was accelerated, but no disease could be discovered in the lungs. As the patient was considered to be moribund, no treatment was adopted, except the application of a blister to the chest. She died six hours later, and it was afterwards ascertained that she had been sulject to dislocation of the arm, that she had been indisposed and peculiar in her manner for four weeks previously, during which time she had been seen only once by a medical man, who considered her hysterical. There were various rickety distortions in the trunk and lower extremities. The vessels of the dura mater and pia mater and the cerebral tissue contained much blood; the arachnoid was not opaque, and there was a considerable amount of reddish watery exudation under it. The lateral ventricles contained a little fluid of the same kind. At the point where the upper wall of the lateral ventricle bends down, there were, on the outer side, between the middle and end of the posterior horn, several hemispherical tumors projecting into the cavity, varying in size, and on section apparently identical in hue and consistency with grey cercbral matter. These deposits extended into the medullary tissue, so as to form circular tumors, which were separated from one another by intervals of white matter. The deposit was greatest at the end of the posterior horn, and here the consistency of the brain was most developed. Both lateral ventricles presented the same appearances, There 
was no other abnormity in the brain. The microscopic cxamination of the new formation exhibited a fine granular mass with granular cells; nerve tubes were not seen. From the remainder of the autopsy, we merely note that the uterus was divided into two compartments by a septum, that there were two cervices and two vaginx, with a single circular hymen.-1bid., Archiv. für Path. Anat., $\& c$.

\section{Zatuliographital Irotices.}

A Practical Treatise on Fractures and Dislocations. By FrANE I $_{\text {AST- }}$ ings HAamltos, M.D., Professor of Surgery in the University of Buffalo ; Surgeon to the Buffalo IIospital of the Sisters of Charity ; Consulting Surgeon to the Buffalo General IIospital, and to the Buffulo City Dispensary. Illustrated with Two IInndred and Eightynine Wood.Cuts. Philadelphii: : Blanchard \& Lea. 1860. Pp. 757.

THIs important work has been long looked for, and will be heartily welcomed in erery quarter of our country. And not only so, but we are greatly mistaken if it does not cominand distinguished respect and obtain enviable distinction abroad. Let us say, at once, that it is emphatically the book upon the suljects of which it treats, and we cannut doubt that it will continue so to be, for an indefinite period of time.

The work of Milgaigne, admiralile and complete as it is, does not cover much of that ground which is at once and completely oceupied by Dr. IIamilton. 'The latter author has placed before us all that Ainerican surgery offers upon the deeply interesting topics which form the subject of his excellent treatise. This, by reason of the difficulty of access to the various reports of cases and methods of practice, the French surgeon was to a great extent precluded from doing, even had he thororonghly attenpted it. Dr. Packard, of Philadelphia, has rendered the profession good service in translating a portion of this great work; and it is to be hoped that he will give us the remainder in an equally satisfactory style. As $\mathrm{Dr}$. IIamilton very truly says, in his prefatory rernarks, "the contributions of American surgeons to this department had to be sought chiefly in medical journals, many of which have long been discontinued, and most of which were inaccessible to the French writer. Even to an American, the labor of exhumation from archives hitherto almost unexplored, has not been small; and it is probable that many ralualle papers have been overlooked; indeed, it is impossible that it should be otherwise."

While we should rejoice, therefore, that an American surgeon and writer has been fuund, so fully competent to present all that is valuable upon the subjects considered, which appertains to American sources, we ought to be fully as much pleased that we have embodied in the available form of a volume, the results of the author's very extended experience, and the carefully prepared opinions upon these difficult and often very embarrassing surgical points, which his close observation and study have so well fitted him to enunciate.

It is not many months since we had the pleasure of seeing certain 